\title{
STRATEGI PENGELOLAAN TAMAN KOTA SEBAGAI DESTINASI WISATA (OBJEK STUDI : TAMAN KOTA 2 BSD, KOTA TANGERANG SELATAN)
}

\author{
Alya Permata $\mathrm{Asti}^{1)}$, Sylvie Wirawati ${ }^{2)}$, Liong Ju Tjung ${ }^{3)}$ \\ 1) Program Studi S1 PWK, Fakultas Teknik, Universitas Tarumanagara, alyaprmt@gmail.com \\ 2) Program Studi S1 PWK, Fakultas Teknik, Universitas Tarumanagara, sylview@ft.untar.ac.id \\ 3) Program Studi S1 PWK, Fakultas Teknik, Universitas Tarumanagara, liongjutjung@yahoo.com
}

Masuk: 07-08-2021, revisi: 24-08-2021, diterima untuk diterbitkan: 23-10-2021

\begin{abstract}
Abstrak
Taman Kota 2 BSD merupakan salah satu ruang publik di Kota Tangerang Selatan yang berfungsi sebagai ruang terbuka hijau yang memiliki luas lahan sebesar $69.834 \mathrm{~m}^{2}$ dan menyediakan berbagai macam fasilitas serta keindahan alam maupun buatan untuk mengatasi permasalahan lingkungan di kawasan perkotaan. Taman Kota 2 BSD telah beroperasi sejak tahun 2006 yang dikembangkan pada awal mula oleh PT. Bumi Serpong Damai Tbk, dan diberikan kepada Pemerintah Kabupaten Tangerang yang kemudian diberikan kepada Pemerintah Kota Tangerang Selatan setelah menjadi daerah otonom sebagai salah satu aset daerah. Taman Kota 2 BSD merupakan salah satu lokasi yang diharapkan dapat menjadi destinasi wisata kota, yang menyediakan fasilitas olahraga, rekreasi, edukasi dan kuliner. Namun pada kenyataan pengelolaan taman ini belum dapat memenuhi kebutuhan masyarakat dan tidak dapat melaksanakan perannya dengan baik sebagai fasilitas umum dan sosial. Tujuan penelitian ini adalah mengetahui potensi dan masalah yang terdapat pada taman, mengetahui kinerja pengelolaan taman dan memberikan usulan strategi pengelolaan untuk Taman Kota 2 BSD. Pengumpulan data dalam penelitian ini dilakukan dengan cara survei lapangan, wawancara, penyebaran kuesioner dan studi pustaka. Untuk mengetahui bagaimana strategi pengelolaan yang dapat diterapkan, penulis menggunakan analisis (lokasi, kondisi fisik, daya tarik, best practice, persepsi dan preferensi pengunjung, strategi pengelolaan). Hasil penelitian penulis yaitu berupa usulan strategi terhadap kegiatan pengelolaan Taman Kota 2 BSD agar tercapai konservasi berkelanjutan.
\end{abstract}

Kata kunci: Pengelolaan; Ruang Terbuka Hijau; Strategi; Taman Kota; Tangerang

\begin{abstract}
Taman Kota 2 BSD is one of the public spaces in South Tangerang City that functions as a green open space which has a land area of 69,834 $\mathrm{m} 2$ and provides various kinds of facilities and natural and artificial beauty to overcome environmental problems in urban areas. Taman Kota 2 BSD has been operating since 2006 which was initially developed by PT. Bumi Serpong Damai Tbk, and given to the Tangerang Regency Government which was then given to the South Tangerang City Government after becoming an autonomous region as one of the regional assets. Taman Kota 2 BSD is one of the locations that is expected to become a city tourist destination, which provides sports, recreation, education and culinary facilities. However, in reality the management of this park has not been able to meet the needs of the community and cannot carry out its role properly as a public and social facility. The purpose of this study was to determine the potential and problems contained in the park, to determine the performance of park management and to propose management strategies for Taman Kota 2 BSD. Data collection in this study was carried out by means of field surveys, interviews, distributing questionnaires and literature studies. To find out how management strategies can be applied, the authors use analysis (location, physical condition, attractiveness, best practice, visitor perceptions and preferences, management strategy). The results of the author's research are in the form of a proposed strategy for the management of Taman Kota 2 BSD in order to achieve sustainable conservation.
\end{abstract}

Keywords: Management; Strategy; Urban Park 


\section{PENDAHULUAN}

\section{Latar Belakang}

Kota Tangerang Selatan merupakan salah satu kota yang berkembang sangat pesat di Indonesia, terletak di Provinsi Banten dan merupakan kota pemekaran dari Kabupaten Tangerang. Pembentukan Kota Tangerang Selatan sebagai daerah otonom tersebut dilakukan dengan tujuan untuk meningkatkan pelayanan dalam bidang pemerintahan, pembangunan, dan kemasyarakatan serta dapat memberikan kemampuan dalam pemanfaatan potensi daerah. Letak geografis Kota Tangerang Selatan yang berbatasan dengan Ibu Kota Jakarta memberikan peluang pada Kota Tangerang Selatan sebagai salah satu daerah penyangga Provinsi DKI Jakarta, selain itu juga sebagai daerah yang menghubungkan Provinsi Banten dengan Provinsi DKI Jakarta dan wilayah lain disekitarnya.

Dengan letak wilayah yang berdekatan dengan ibukota menjadikan Kota Tangerang Selatan sebagai salah satu kota yang strategis. Kenaikan laju pertumbuhan penduduk Kota Tangerang Selatan, dimana orientasi pembangunan kota saat ini ditujukan untuk perumahan dan fasilitas penunjang seperti pendidikan, pemerintahan, perindustrian dan perdagangan. Sebagai bentuk untuk menjaga kelestarian wilayah perkotaan, Pemerintah Kota Tangerang Selatan mencantumkan pembangunan dan pengembangan RTH pada Peraturan Daerah Kota Tangerang Selatan Nomor 15 Tahun 2011 tentang Rencana Tata Ruang Wilayah (RTRW) Tahun 2011-2031 yang menjadi fungsi koordinasi dan pengendalian pembangunan serta penataan ruang perkotaan di masa mendatang.

Taman Kota 2 BSD merupakan salah satu ruang publik di Kota Tangerang Selatan yang terletak di kawasan pergudangan Taman Tekno yang dimanfaatkan oleh masyarakat dari dalam maupun dari luar Kota Tangerang Selatan sebagai fasilitas untuk berolahraga dan berekreasi. Berdasarkan fakta lapangan ditemukan berbagai masalah pada pengelolaan taman seperti terdapat kerusakan pada fasilitas yang tersedia pada taman tidak terawat dengan baik dan kurangnya kelengkapan beberapa fasilitas untuk menunjang kebutuhan pengunjung serta lingkungan taman yang kurang terjaga sehingga taman belum dapat melaksanakan perannya dalam memberi pelayanan publik kepada masyarakat dengan baik, hal tersebut menunjukkan pentingnya strategi dalam mengelola suatu taman kota yang menjadi dasar bagi penulis untuk melakukan penelitian pada Taman Kota 2 BSD.

\section{Rumusan Permasalahan}

Rumusan permasalahan dalam penelitian ini adalah pada Taman Kota 2 BSD masih dapat dijumpai berbagai permasalahan yang terkait dengan pengelolaan taman yang kurang diperhatikan oleh pemerintah setelah dilakukan revitalisasi berdasarkan survei lapangan yang dilakukan penulis, permasalahan - permasalahan tersebut dapat dilihat dari kondisi fisik fasilitas umum pada taman yang tidak terawat dengan baik sehingga mengalami kerusakan, adanya pedagang kaki lima (PKL) liar yang membangun bangun non-permanen berupa kios - kios kecil atau menggunakan gerobak yang menyebar di area taman, sumber daya yang kurang juga menyebabkan permasalahan pada taman, seperti terjadinya tindak kriminalitas pencurian karena minimnya fasilitas keamanan dan kurangnya kebersihan lingkungan taman. Permasalahan yang terdapat di taman ini diakibatkan tidak adanya sistem pengelolaan taman yang terstruktur dengan baik sehingga menyebabkan menurunnya kualitas taman sebagai ruang publik yang menunjang kehidupan masyarakat dan lingkungan perkotaan.

\section{Tujuan}

Adapun tujuan penelitian ini adalah mengidentifikasi kondisi fisik dan lingkungan sekitar Taman Kota 2 BSD untuk mengetahui potensi dan masalah yang terdapat pada Taman Kota 2 BSD 
dengan melakukan evaluasi kondisi dan kinerja pengelolaan eksisting di Taman Kota 2 BSD BSD agar dapat dilakukan penyusunan rekomendasi strategi pengelolaan yang baik dan efektif terhadap pengelolaan Taman Kota 2 BSD sebagai ruang terbuka hijau publik di Kota Tangerang Selatan.

\section{KAJIAN LITERATUR}

\section{Ruang Terbuka Hijau}

Menurut Peraturan Menteri Pekerjaan Umum No. 5 Tahun 2008 tentang Pedoman Penyediaan dan Pemanfaatan Ruang Terbuka Hijau di Kawasan Perkotaan, Ruang terbuka hijau adalah area memanjang/jalur mengelompok, yang penggunaannya bersifat ruang - ruang terbuka pada suatu wilayah perkotaan yang diisi oleh tumbuhan, tanaman, dan vegetasi, baik yang tumbuh secara alamiah maupun yang sengaja ditanam guna mendukung manfaat langsung atau tidak langsung yang dihasilkan oleh RTH dalam kota tersebut yaitu keamanan, kenyamanan, kesejahteraan, dan keindahan wilayah perkotaan tersebut. Sedangkan menurut Hadi Purnomo (1995), ruang terbuka hijau diartikan sebagai bentang lahan terbuka yang di dalamnya ditumbuhi berbagai tumbuhan, dengan pepohonan sebagai tumbuhan penciri utamanya, pada berbagai strata, mulai dari semak, perdu, rerumputan dan tumbuhan penutup tanah lainnya tanpa bangunan yang memiliki ukuran, bentuk dan batas geografis tertentu dengan status penguasaan apapun.

\section{Taman Kota}

Menurut Berdasarkan Peraturan Menteri Pekerjaan Umum No. 5 Tahun 2008 tentang Pedoman Penyediaan dan Pemanfaatan Ruang Terbuka Hijau di Kawasan Perkotaan, Taman kota adalah taman yang ditujukan untuk melayani penduduk satu kota atau bagian wilayah kota. Taman ini melayani minimal 480.000 penduduk dengan standar minimal $0,3 \mathrm{~m} 2$ per penduduk kota, dengan luas taman minimal $144.000 \mathrm{~m} 2$. Taman ini dapat berbentuk sebagai RTH (lapangan hijau), yang dilengkapi dengan fasilitas olahraga dan rekreasi, dan kompleks olahraga dengan minimal RTH $80 \%$ - 90\%. Semua fasilitas tersebut terbuka untuk umum.

\section{Strategi Pengelolaan}

Dalam suatu taman kota, pengelolaan menjadi salah satu unsur penting untuk menjaga keberlanjutan taman kota agar sesuai dengan fungsi taman kota sebagai ruang bagi aktivitas masyarakat kota dan juga diperlukan bagi kualitas lingkungan hidup perkotaan. Menurut Inglis dkk (2005), terdapat aspek sistem pengelolaan taman berkelanjutan yaitu klasifikasi taman, teman \& karakteristik pengelolaan taman, kepegawaian, pendanaan \& dampak, pengelolaan pengunjung, pengelolaan aset, pemasaran \& distribusi serta pemerintahan. Sedangkan menurut V. F. Kasyanov \& R. V. Silin (2019), dalam melakukan pengelolaan taman kota terdapat kriteria kriteria penilaian yang berdasarkan empat fungsi utama taman, yaitu ekologis, rekreasi, ergonomis, dan estetika serta keamanan. Pada penelitian ini penulis menggunakan 10 aspek pengelolaan taman dari gabungan kedua studi tersebut, yaitu, klasifikasi taman, aksesibilitas taman, penggunaan taman, pengelolaan pengunjung taman, pengelolaan aset taman, pengelolaan lingkungan taman, keterlibatan pihak lain, pemasaran \& distribusi, kepegawaian serta pendanaan \& dampak.

\section{METODE PENELITIAN}

Jenis penelitian yang digunakan adalah deskriptif kualitatif. Pada penelitian terdapat dua metode yang digunakan yaitu metode pengumpulan data dan metode pengolah data. Pada metode pengumpulan data terdapat dua jenis data yaitu data primer yang didapatkan melalui observasi lapangan, wawancara, kuesioner dan data sekunder didapatkan melalui sumber pustaka yang relevan seperti artikel, buku, jurnal, skripsi, data instansi terkait. Untuk metode 
pengolahan data penelitian ini dilakukan dengan menggunakan analisis lokasi, analisis kondisi fisik, analisis daya tarik, analisis best practice, analisis persepsi dan preferensi pengunjung serta analisis strategi pengelolaan.

\section{DISKUSI DAN HASIL}

\section{Profil Taman Kota 2 BSD}

Taman Kota 2 BSD merupakan salah satu taman kota di Kota Tangerang Selatan yang berada di kawasan pergudangan Taman Tekno, Kelurahan Ciater, Kecamatan Serpong dengan luas area sebesar 69.834 m2 Taman Kota 2 BSD yang memiliki dua akses untuk memasuki taman karena objek studi menghadap pada dua sisi jalan. Untuk masuk ke dalam taman para pengunjung dapat melalui Jalan Tekno Widya dan Jalan Ciater Barat. Taman Kota 2 BSD pertama kali dibuka pada tahun 2006 yang dikembangkan oleh developer PT Bumi Serpong Damai Tbk berdekatan setelah dilakukan pengembangan Taman Kota 1 BSD di Jalan Letnan Sutopo, Kelurahan Lengkong Gudang Timur, Kecamatan Serpong sebagai salah satu bentuk untuk mengatasi permasalahan perkotaan di kawasan pusat perdagangan berskala besar yang berada di Kota Tangerang Selatan dan sebagai wujud Corporate Social Responsibility sebuah kawasan hunian di daerah Serpong dalam mewujudkan kota yang bersih dan nyaman dengan membangun fasilitas umum dan fasilitas sosial yang bersifat sebagai ruang terbuka hijau publik yaitu Taman Kota. Taman Kota 2 BSD disediakan sarana dan prasarana yang dapat mendukung berbagai macam kegiatan yang dapat dilakukan oleh pengunjung, dimana pengunjung dapat melakukan berbagai jenis kegiatan, seperti berolahraga, berekreasi, berkumpul dengan komunitas, sekedar bersantai, serta melihat keindahan alam.
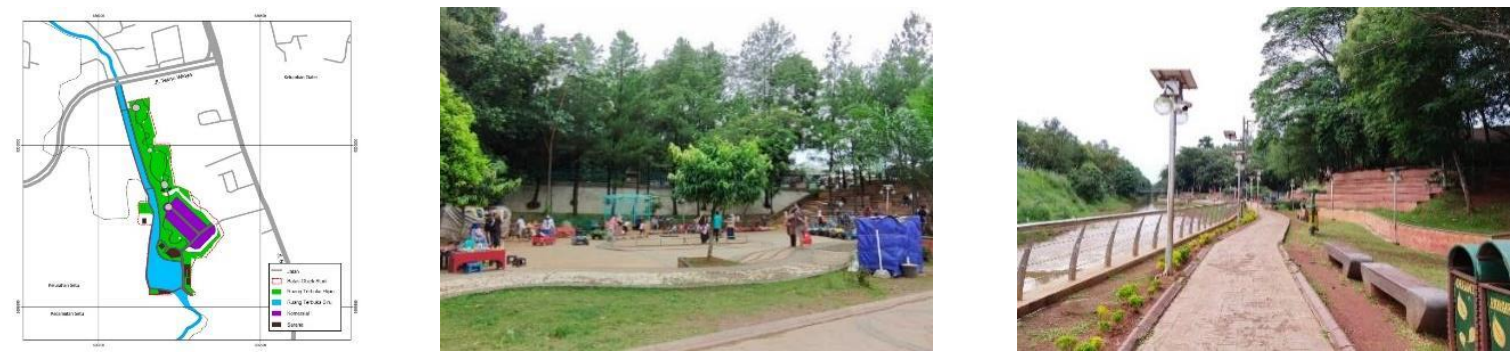

Gambar 1. Gambaran Umum Objek Studi

Sumber: Hasil Olahan Penulis, 2021

\section{Analisis Lokasi}

Analisis ini bertujuan untuk mengidentifikasi karakteristik faktor eksternal dan internal pada objek studi dengan mengetahui penggunaan lahan, aksesibilitas, jaringan transportasi umum, penggunaan lahan eksisting aktivitas. Kondisi penggunaan lahan di sekitar Taman Kota 2 BSD adalah peruntukan hunian, industri, dan komersial dan yang paling mendominasi adalah hunian. Taman Kota 2 BSD memiliki aksesibilitas yang cukup bagus karena dapat dijangkau dari berbagai daerah. Pada Taman Kota 2 BSD terdapat 2 pintu masuk, pintu 1 di bagian utara taman di Jalan Tekno Widya dan pintu 2 di bagian timur taman di Jalan Ciater Barat. Akses yang dapat dilalui pengunjung dari Jakarta dengan menggunakan Jalan Tol Jakarta Outer Ring Road. Terdapat juga alternatif akses bagi pengunjung dari luar Jakarta seperti, Kota Tangerang dan Parung. Untuk pengunjung dari Kota Tangerang dapat melalui Jalan Tol Jakarta - Tangerang dan Jalan Jenderal Sudirman. Sedangkan pengunjung dari Parung dapat melalui Jalan Permata dan Jalan Jakarta Bogor. Untuk pencapaian menuju taman Kota 2 BSD menggunakan kendaraan, tidak hanya dapat diakses menggunakan kendaraan pribadi tetapi juga dapat diakses menggunakan transportasi umum sebagai sarana atau alat yang membantu mobilitas penduduk dari suatu tempat ke tempat yang lain, yang disediakan oleh Pemerintah Kota Tangerang Selatan berupa Angkot, Bus Besar dan KRL Commuter Line. Bagi pejalan kaki, jalur pedestrian di sekitar kawasan 
Taman Kota 2 BSD hanya terdapat di Jalan Tekno Widya, pintu masuk bagian utara taman sehingga taman belum memenuhi kebutuhan dan kenyamanan pengunjung.

\section{Analisis Kondisi Fisik}

Analisis bertujuan untuk mengetahui potensi dan masalah dengan mengidentifikasi bagaimana kondisi fisik eksisting serta kebutuhan sarana dan prasarana bagi pengunjung Taman Kota 2 BSD. Pada Taman Kota 2 BSD kondisi sarana secara keseluruhan cukup baik, tetapi masih dapat ditemukan beberapa sarana yang mengalami kerusakan seperti jogging track, permukaan lantai skatepark, kerusakan pada alat toilet, tempat makan yang kecil tidak dapat menampung banyaknya jumlah pedagang di taman akibat tingginya masyarakat yang berkunjung ke taman sehingga memunculkan pedagang kaki lima yang berjualan di area taman yang tidak tertata dengan baik. Sedangkan kondisi prasarana pada Taman Kota 2 BSD secara keseluruhan masih kurang seperti kebersihan taman yang masih kurang terjaga sehingga masih dapat ditemukan sampah yang berserakan di area taman, kebutuhan dan kualitas air bersih, minimnya daya listrik dan penerangan dan pemeliharaan vegetasi yang berada di taman. Pada taman tidak terdapat pihak pengelola yang bertanggung jawab atas secara keseluruhan elemen - elemen yang dimiliki Taman Kota 2 BSD sehingga pengelolaan yang terlaksana tidak tertera dengan baik. Dapat diketahui bahwa masih terdapat sarana dan juga prasarana pada Taman Kota 2 BSD yang masih membutuhkan peningkatan baik dari sisi pengelolaan maupun pemenuhan kebutuhan untuk menunjang aktivitas pengunjung Taman Kota 2 BSD.

\section{Analisis Daya Tarik}

Analisis bertujuan untuk mengetahui potensi atraksi atau kegiatan pada Taman Kota 2 BSD yang dapat dikembangkan. Analisis ini mengacu kepada penyediaan komponen pariwisata yang ada pada objek studi dengan melihat kegiatan dan ketertarikan pengunjung terhadap potensi yang dimiliki Taman Kota 2 BSD yang terbagi menjadi dua klasifikasi yaitu potensi internal berupa aspek non fisik dan potensi eksternal berupa aspek fisik dan apa yang menurut pengujung harus ditambahkan untuk meningkatkan kunjungan dan kepuasan pada Taman Kota 2 BSD. Hal ini berkaitan dengan keunikan, keindahan, dan nilai keanekaragaman kekayaan alam, budaya dan hasil buatan manusia yang menjadi karakteristik Taman Kota 2 BSD.

Tabel 1. Analisis SWOT

\begin{tabular}{|c|c|c|}
\hline & Strengths & Weakness \\
\hline & $\begin{array}{ll}\text { - } & \text { Lokasi taman strategis } \\
\text { - } & \text { Kemudahan aksesibilitas menuju } \\
\text { - } & \text { Meman } \\
\text { - } & \text { Memiliki luas yang cukup besar } \\
\text { - } & \text { Mnik (ruang hijau dan ruang biru) } \\
\text { - } & \text { yenyediakan fasilitas taman } \\
\text { - } & \text { Menyediakan kesempatan } \\
\text { rekreasi }\end{array}$ & $\begin{array}{l}\text { - } \quad \text { Manajemen taman dibagi } \\
\text { menjadi } 2 \text { unit pelayanan } \\
\text { Kurangnya pemeliharaan } \\
\text { fasilitas dan lingkungan taman } \\
\text { - } \quad \text { Kurangnya kelengkapan fasilitas } \\
\text { untuk kebersihan, kebutuhan air } \\
\text { bersih, kelistrikan \& penerangan } \\
\text { serta keamanan } \\
\text { Banyaknya PKL yang tersebar di } \\
\text { area objek studi sehingga } \\
\text { terlihat tidak tertata rapi }\end{array}$ \\
\hline Opportunities & $S-0$ & $w-0$ \\
\hline $\begin{array}{l}\text { - Lokasi taman berada di } \\
\text { zona hunian \& industri } \\
\text { - Tidak terdapat taman } \\
\text { sejenis di sekitar lokasi } \\
\text { taman }\end{array}$ & $\begin{array}{l}\text { - Lokasi taman yang strategis dan } \\
\text { akses yang mudah dapat } \\
\text { meningkatkan potensi } \\
\text { pengunjung dari berbagai daerah } \\
\text { - Potensi pengembang daya tarik } \\
\text { yang dimiliki }\end{array}$ & $\begin{array}{l}\text { Meningkatkan pemeliharaan } \\
\text { fasilitas } \\
\text { - Meningkatkan pemeliharaan } \\
\text { lingkungan } \\
\text { - Mengimplementasikan hasil } \\
\text { best practice pengelolaan dari }\end{array}$ \\
\hline
\end{tabular}




\begin{tabular}{|c|c|c|}
\hline Threats & $\mathbf{S}-\mathbf{T}$ & $\mathbf{W}-\mathbf{T}$ \\
\hline $\begin{array}{ll}\text { - } & \text { Manajemen tidak } \\
\text { konsisten karena } \\
\text { perubahan } \\
\text { administratif atau } \\
\text { variasi pengawas } \\
\text { pengelolaan } \\
\text { Dana terbatas } \\
\text { Kurangnya kesadaran } \\
\text { masyarakat untuk } \\
\text { menjaga taman }\end{array}$ & $\begin{array}{l}\text { Meningkatkan pengelolaan dengan } \\
\text { melakukan pemeliharaan dan } \\
\text { perawatan elemen pada taman untuk } \\
\text { mengatasi kerusakan sarana dan } \\
\text { prasarana dalam jangka pendek, } \\
\text { menengah dan panjang. }\end{array}$ & $\begin{array}{l}\text { - Pembuatan peraturan dan } \\
\text { pemasangan signage informasi } \\
\text { pada taman } \\
\text { Meningkatkan kedisiplinan } \\
\text { dalam memberi pengetahuan } \\
\text { kepada pengunjung dan } \\
\text { keamanan pada objek studi }\end{array}$ \\
\hline
\end{tabular}

- Terdapat rencana pengembangan taman oleh pemerintah kota

- Menumbuhkan hubungan kerja sama dan mitra melalui perluasan jangkauan

Sumber: Hasil Olahan Penulis,2021

\section{Analisis Best Practice}

Analisis ini bertujuan untuk mengetahui pengelolaan objek studi pembanding yang memiliki pedoman standarisasi pengelolaan taman yang hampir sama dalam melakukan penerapan pengelolaan pada objek studi. Taman yang dijadikan sebagai benchmarking adalah Taman Bungkul dan Golden Gate Park yang memiliki konsep taman sejenis dengan objek studi yaitu taman kota.Kajian yang dapat menjadi contoh dari Golden Gate Park adalah memiliki sumber daya manusia yang memadai juga berkompetisi dan terlatih dengan sistem pengelolaan taman yang terorganisir, pemeliharaan aset taman dengan mengandalkan skala prioritas yang dilakukan secara rutin dan konsisten sehingga kondisinya selalu dalam keadaan terawat dan terjaga dengan baik, pengelolaan lingkungan taman dengan selalu menjaga kebersihan dan pengelolaan sampah yang baik yang bermitra dengan pihak ketiga, adanya anggaran tetap maupun anggaran fleksibel untuk melakukan pengelolaan taman, adanya komunitas yang dikelola oleh pengelola taman maupun komunitas lain yang dapat menyubangkan ide dan tenaga terhadap keberlanjutan taman serta peningkatan daya tarik seperti festival atau acara kesenian lainnya untuk meningkatkan kesenangan pengunjung. Sedangkan kajian yang dapat dicontoh dari Taman Bungkul selain memiliki pengelolaan taman yang cukup baik, kajian lain yang dapat diambil yaitu penempatan dan penertiban PKL dengan membuat Sentra PKL sehingga mencukupi pedagang pada taman.

\section{Analisis Persepsi dan Preferensi Pengunjung}

Analisis ini bertujuan untuk memperoleh karakteristik, tanggapan dan penilaian pengunjung terhadap kinerja pengelolaan dan penerapannya di Taman Kota 2 BSD. Dalam menentukan jumlah responden yang dibutuhkan dalam analisis ini, penulis melakukan perhitungan dengan menggunakan teknik random sampling dan rumus Slovin. Berdasarkan data jumlah pengunjung yang diperoleh tahun 2021, jumlah rata - rata pengunjung Taman Kota 2 BSD dalam setiap minggunya sebesar 873 orang, maka didapatkan jumlah sampel minimal yaitu sebesar 90 responden dengan mengambil total sampel untuk kuesioner yang disebarkan kepada sebesar 100 responden. Selain untuk mengetahui pandangan pengunjung terhadap pengelolaan pada Taman Kota 2 BSD, penyebaran kuesioner juga untuk mengidentifikasi pengunjung berdasarkan karakteristik. 
Tabel 3. Nilai Kerja dan Nilai Kepentingan Menurut Pengunjung

\begin{tabular}{|c|c|c|c|c|}
\hline No & $\begin{array}{c}\text { Aspek } \\
\text { Pengelolaan }\end{array}$ & Indikator Penilaian & $\begin{array}{c}\text { Nilai } \\
\text { Kinerja }\end{array}$ & $\begin{array}{c}\text { Nilai } \\
\text { Kepentingan }\end{array}$ \\
\hline 11 & \multirow{3}{*}{ Klasifikasi Taman } & Penataan lanskap taman & 4,28 & 4,60 \\
\hline 12 & & Struktur ruang taman mengikuti kebijakan & 4,25 & 4,02 \\
\hline 13 & & Luas kawasan taman & 4,17 & 4,52 \\
\hline 14 & \multirow{4}{*}{$\begin{array}{l}\text { Aksesibilitas } \\
\text { Taman }\end{array}$} & Kondisi jalan menuju taman & 4,28 & 4,70 \\
\hline 15 & & Keterjangkauan taman dengan transportasi umum & 4,05 & 4,45 \\
\hline 16 & & Ketersediaan papan petunjuk lokasi taman & 2,57 & 3,95 \\
\hline 17 & & Kondisi akses masuk menuju taman & 4,17 & 4,65 \\
\hline 18 & \multirow{2}{*}{$\begin{array}{l}\text { Penggunaan } \\
\text { Taman }\end{array}$} & Aktivitas yang dapat dilakukan di taman bervariasi & 4,35 & 4,70 \\
\hline 19 & & $\begin{array}{l}\text { Keberadaan taman terhubung dengan fasilitas kota } \\
\text { lainnya }\end{array}$ & 3,63 & 3,84 \\
\hline 20 & \multirow{20}{*}{$\begin{array}{c}\text { Pengelolaan } \\
\text { Pengunjung } \\
\text { Taman }\end{array}$} & Ketersediaan dan kondisi jogging track & 2,87 & 4,57 \\
\hline 21 & & Ketersediaan dan kondisi fitness outdoor & 4,05 & 4,52 \\
\hline 22 & & Ketersediaan dan kondisi skatepark & 3,00 & 4,50 \\
\hline 23 & & Ketersedaian dan kondisi lapangan gateball & 3,90 & 4,45 \\
\hline 24 & & Ketersediaan dan kondisi outdoor playground & 3,12 & 4,15 \\
\hline 25 & & Ketersediaan dan kondisi open stage & 4,17 & 4,60 \\
\hline 26 & & Ketersediaan dan kondisi amphitheater & 4,28 & 4,52 \\
\hline 27 & & $\begin{array}{l}\text { Ketersediaan dan kondisi elemen budaya (rumah } \\
\text { blandongan) }\end{array}$ & 4,35 & 4,45 \\
\hline 28 & & Ketersediaan dan kondisi tempat makan (kantin) & 3,10 & 4,62 \\
\hline 29 & & Ketersediaan dan kondisi peribadatan (mushola) & 2,94 & 4,20 \\
\hline 30 & & Ketersediaan dan kondisi toilet & 2,76 & 4,68 \\
\hline 31 & & Ketersediaan dan kondisi tempat parkir & 3,78 & 4,65 \\
\hline 32 & & $\begin{array}{l}\text { Ketersediaan dan kondisi jalur pejalan kaki tepi } \\
\text { sungai }\end{array}$ & 4,35 & 4,60 \\
\hline 33 & & $\begin{array}{l}\text { Ketersediaan dan kondisi fasilitas untuk disabilitas } \\
\text { pada taman }\end{array}$ & 3,06 & 4,20 \\
\hline 34 & & $\begin{array}{l}\text { Ketersediaan dan kondisi fasilitas keamanan pada } \\
\text { taman }\end{array}$ & 2,63 & 4,62 \\
\hline 35 & & Ketersediaan dan kondisi sanitasi pada taman & 2,87 & 4,43 \\
\hline 36 & & $\begin{array}{l}\text { Ketersediaan dan kondisi kelistrikan dan } \\
\text { penerangan }\end{array}$ & 3,06 & 3,95 \\
\hline 37 & & Ketersediaan dan kondisi vegetasi pada taman & 3,12 & 3,88 \\
\hline 38 & & Ketersediaan dan kondisi signage pada taman & 2,94 & 4,08 \\
\hline 39 & & $\begin{array}{l}\text { Pusat pelayanan informasi dan pengaduan } \\
\text { pengunjung taman }\end{array}$ & 2,77 & 4,15 \\
\hline 40 & \multirow{3}{*}{$\begin{array}{l}\text { Pengelolaan Aset } \\
\text { Taman }\end{array}$} & Pemeliharaan terhadap fasilitas taman & 3,00 & 4,75 \\
\hline 41 & & Keanekaragaman vegetasi pada taman & 4,14 & 4,18 \\
\hline 42 & & Jenis tanaman yang identik pada taman & 3,98 & 3,97 \\
\hline 43 & \multirow{3}{*}{$\begin{array}{c}\text { Pengelolaan } \\
\text { Lingkungan } \\
\text { Taman }\end{array}$} & Kondisi kebersihan lingkungan taman & 2,54 & 4,68 \\
\hline 44 & & Ketersediaan tempat sampah pada taman & 2,65 & 4,20 \\
\hline 45 & & Pengelolaan sampah taman & 3,10 & 4,57 \\
\hline 46 & & Terdapat komunitas pada taman & 3,86 & 3,92 \\
\hline
\end{tabular}




\begin{tabular}{cclccc}
47 & $\begin{array}{c}\text { Keterlibatan } \\
\text { Pihak Lain }\end{array}$ & Terdapat kegiatan edukasi pada taman & 2,77 & 4,08 \\
\hline 48 & $\begin{array}{c}\text { Pemasaran \& } \\
\text { Distribusi }\end{array}$ & Kemudahan dalam mengakses informasi taman & 4,05 & 4,40 \\
\hline 49 & Kepegawaian & Ketersediaan staf pengelola taman yang memadai & 2,76 & 4,75 \\
\hline 50 & $\begin{array}{c}\text { Pendanaan \& } \\
\text { Dampak }\end{array}$ & $\begin{array}{l}\text { Keberadaan taman memberikan dampak ekonomi, } \\
\text { sosial dan budaya }\end{array}$ & 4,30 & 4,13 \\
\hline
\end{tabular}

Sumber: Hasil Olahan Penulis, 2021

Berdasarkan hasil penyebaran kuesioner, didapatkan rata - rata nilai kinerja dan nilai kepentingan seluruh indikator yang diidentifikasi dalam diagram kartesius terbagi menjadi 4 kuadran skala prioritas. Kuadran - kuadran tersebut dibatasi oleh dua buah garis yang berpotongan tegak lurus yaitu $\mathrm{x}$ dan $\mathrm{y}$, dimana garis $\mathrm{x}$ merupakan rata - rata nilai kinerja yaitu sebesar 4,37 dan garis y adalah rata - rata nilai kepentingan yaitu sebesar 3,50. Dapat dilihat bahwa selain adanya aspek pengelolaan dan indikator penilaian yang membutuhkan perbaikan, tetapi juga perlu dipertahankan.

\section{Analisis Strategi Pengelolaan}

Analisis ini bertujuan untuk merumuskan rekomendasi strategi pengelolaan yang dapat digunakan pada Taman Kota 2 BSD melalui penentuan alternatif dari berbagai hasil analisis dan studi sebelumnya yang terkait dengan pengelolaan untuk menyelesaikan permasalahan pada objek studi. Analisis dilakukan dengan penetapan kriteria dengan melihat karakteristik dasar objek studi untuk mengukur hasil kebijakan, jangka waktu dan dampak dari program pengelolaan pada Taman Kota 2 BSD agar mencapai tujuan penelitian.

Klasifikasi Taman

Keberadaan Taman Kota 2 BSD merupakan sebuah salah satu bentuk fisik berupa ruang terbuka hijau non alami bersifat publik yang berada di Kota Tangerang Selatan yang menggunakan konsep taman kota dengan area hijau yang dipadukan dengan area biru berupa aliran sungai kecil yang melintasi kawasan taman. Berdasarkan Rencana Tata Ruang Wilayah Kota Tangerang Selatan Tahun 2031, lahan Taman Kota 2 BSD merupakan lahan yang diperuntukkan sebagai perumahan kepadatan sedang dan peruntukan lainnya yang mendukung kegiatan permukiman. Dalam melakukan pengembangan terhadap pengelolaan Taman Kota 2 BSD seharusnya dapat dibuat sejalan dengan kondisi dan fungsi ekologis taman serta didukung oleh adanya upaya pemerintah daerah dengan memperhatikan kebijakan yang ada yaitu Peraturan Menteri Pekerjaan Umum No. 5 Tahun 2008 tentang Pedoman Penyediaan dan Pemanfaatan Ruang Terbuka Hijau di Kawasan Perkotaan yang berdasarkan pada Undang - Undang No. 26 Tahun 2007 tentang Penataan Ruang.

\section{Aksesibilitas Taman}

Untuk menuju Taman Kota 2 BSD kondisi jalan yang tersedia sudah cukup baik tetapi tidak terdapat papan penunjuk arah di sekitar taman sehingga dapat menyulitkan pengunjung terutama bagi yang pertama kali mengunjungi Taman Kota 2 BSD, maka diperlukan pemasangan papan penunjuk arah di sekitar kawasan Taman Kota 2 BSD guna memudahkan pengunjung menemukan lokasi Taman Kota 2 BSD. Penambahan signage dan papan informasi pada Taman Kota 2 BSD diperlukan karena saat ini jumlahnya masih sangat minim sehingga dapat memudahkan pengunjung mencari lokasi fasilitas dan meningkatkan pengetahuan pengunjung terkait vegetasi yang dapat ditemukan pada Taman Kota 2 BSD. Pintu masuk ke taman pada kawasan sekitar Taman Kota 2 BSD di Jalan Ciater Barat tidak terdapat pedestrian dan jalur sepeda, maka perlu dilakukan pengelolaan penambahan jalur pedestrian beserta jalur sepeda dengan mengajukan permohonan kepada Dinas Perhubungan Kota Tangerang Selatan agar 
melakukan pembangunan atas jalur tersebut di sepanjang Jalan Ciater Barat.

\section{Penggunaan Taman}

Dengan memiliki luas Taman Kota 2 BSD yang cukup besar yaitu $69.834 \mathrm{~m} 2$ sebagai fasilitas umum berupa ruang publik masyarakat Kota Tangerang Selatan dan sekitarnya, terdapat berbagai macam aktivitas yang dapat dilakukan pengunjung di Taman Kota 2 BSD. Dengan konsep taman kota yang dikembangkan selain menjadi tempat olahraga juga menjadi tempat rekreasi yang mempunyai nilai sosial, ekonomi dan edukatif. Taman Kota 2 BSD menghasilkan berbagai macam aktivitas yang dapat dilakukan oleh pengunjung. Aktivitas pengunjung di Taman Kota 2 BSD didukung dengan ketersediaan fasilitas yang beragam dan adanya usaha masyarakat lokal yang membuka jasa seperti peminjaman permainan bagi anak - anak, peminjaman alat lainnya untuk menikmati keindahan taman dan penjualan tanaman hias serta wisata kuliner yang menjadi daya tarik taman, maka perlu dipertahankan oleh pengelola dengan melakukan kerja sama atau bermitra dengan masyarakat lokal.

\section{Pengelolaan Pengunjung Taman}

Sebagai ruang publik yang memiliki tingkat kunjungan yang cukup tinggi pengelolaan terhadap pengunjung taman menjadi sistem yang komprehensif dengan kerangka acuan dan menggabungkan elemen - elemen yang termasuk dalam pengembangan potensi yang dimiliki taman, yaitu pengembangan terhadap fasilitas maupun daya tarik lainnya dengan mengidentifikasi jumlah dan kegiatan setiap zona pada taman untuk memantau kegiatan yang dilakukan pengunjung, mengelola dampak yang dihasilkan dari aktivitas yang dilakukan pada taman serta pelayanan yang diberikan staf kepada pengunjung. Pengembangan pengelolaan Taman Kota 2 BSD dengan penambahan fasilitas yang perlu dilakukan, yaitu akses internet nirkabel (WiFi atau HotSpot), sentra PKL, charging station, kran air siap minum (KASM) serta pusat pelayanan informasi dan pengaduan pengunjung taman

\section{Pengelolaan Aset Taman}

Dalam melakukan pengelolaan aset taman dibutuhkan pencatatan data atau informasi terhadap kondisi maupun kinerja fasilitas dan aset bersejarah yang dijadikan sebagai acuan sehingga memiliki catatan riwayat pemeliharaan yang terdata dengan baik. Penjadwalan secara konsisten dan rutin secara berkala dan teratur dalam melakukan pemeliharaan aset taman serta inspeksi lapangan dan kategorisasi terhadap aset yang dimiliki dan penggunaannya yang masih relevan. Pada Taman Kota 2 BSD masih terdapat aset taman yang perlu dilakukan perbaikan seperti perbaikan terhadap perkerasan jogging track, perbaikan pada permukaan area skatepark, perbaikan pada pintu toilet dan mengganti alat penunjangnya yang mengalami kerusakan, meningkatkan keamanan taman dengan menambahkan petugas yang berpatroli keliling setiap jam dan pemasangan cctv pada beberapa titik taman serta membuat peraturan dan sanksi yang ketat bagi pengunjung yang melanggar. Konservasi khususnya bagi vegetasi di Taman Kota 2 BSD dapat dilakukan dengan penanaman dan penaburan bibit - bibit tanaman hias yang bervariasi untuk menambah keindahan bagi Taman Kota 2 BSD.

\section{Pengelolaan Lingkungan Taman}

Dalam mengelola lingkungan taman diperlukan kerangka kerja yang menekankan pada integritas ekologi yang ada untuk menjaga resiko terhadap kelestarian lingkungan Taman Kota 2 BSD. Pemeliharaan lingkungan dilakukan dengan pemangkasan terhadap vegetasi yang membutuhkannya karena tidak semua vegetasi memerlukan pemangkasan, upaya perawatan ini mengacu pada manfaat atau tujuan tertentu. Selain itu, penyiraman pada vegetasi yang memadai perlu dilakukan untuk menyuburkan tanaman dengan memenuhi kebutuhan nutrisi mineral vegetasi. Pada Taman Kota 2 BSD kondisi vegetasi masih perlu ditingkatkan karena 
masih terdapat vegetasi yang layu atau kering dan ranting pohon yang panjang sehingga menghalangi jalan pada taman perlu dilakukan pemangkasan setiap 2 minggu. Kebersihan pada Taman Kota 2 BSD saat ini belum dapat memenuhi harapan pengunjung, sehingga perlu ditingkatkan dengan melakukan penambahan tempat sampah pada beberapa titik taman yang ramai pengunjung serta penambahan jumlah petugas kebersihan yang memadai dengan membuat penjadwalan kebersihan lingkungan taman yang dilakukan secara rutin untuk memastikan lingkungan taman tetap terawat dengan baik. Pengelolaan sampah pada taman dapat dilakukan dengan tetap menjalin kerja sama dengan Dinas Lingkungan Hidup (DLH) Kota Tangerang Selatan sebagai dinas yang mengelola persampahan Taman Kota 2 BSD sehingga pihak pengelola tidak perlu melakukan pengelolaan sampah sendiri, selain dapat membahayakan lingkungan taman dan juga menghambat kinerja pengelolaan taman.

\section{Keterlibatan Pihak Lain}

Salah satu hal penting yang membantu berjalannya pengelolaan taman adalah adanya keterlibatan pihak lain untuk memperoleh hasil pada tingkat sosial. Keterlibatan pihak lain merupakan upaya terhadap pengembangan taman yang terdiri dari kontribusi langsung berupa sukarelawan yang berpartisipasi dalam dalam pemeliharaan taman dan mengadakan pertunjukan seni atau event lainnya serta kontribusi tidak langsung berupa donasi yang memastikan bahwa pihak pengelola dapat memahami dan responsif terhadap kebutuhan, pandangan, dan harapan masyarakat dalam pemilihan keputusan alternatif. Keterlibatan tersebut juga dapat menggerakan masyarakat secara individual dan memberikan program edukasi terhadap penggunaan dan kepekaan kepedulian untuk menjaga dan merawat taman yang memberikan banyak maaf bagi kehidupan manusia. Dengan adanya keterlibatan pihak seperti komunitas dan organisasi diharapkan dapat meningkatkan interaksi sosial dengan membangun hubungan yang baik antar pihak pengelola dengan dengan masyarakat dan menjaga keberlanjutan taman.

\section{Pemasaran \& Distribusi}

Kegiatan penyampaian informasi tentang suatu taman kota perlu dilakukan pembagian informasi yang tidak hanya berfokus kepada pemasaran produk tetapi juga melakukan pemasaran sosial. Penyebaran informasi dapat dilakukan secara elektronik maupun media publikasi lainnya seperti koran dan majalah. Pemasaran pada Taman Kota 2 BSD sudah cukup terjangkau, tetapi informasi tentang taman yang dapat diperoleh dari berbagai sistem distribusi belum lengkap dan akurat sehingga kebutuhan bagi masyarakat umum belum terpenuhi, maka pihak pengelola taman perlu memperbaharui data melalui media sosial yang disertakan dengan foto kondisi taman terbaru dan memasukkan informasi tentang taman ke dalam situs resmi. Selain itu, dengan mengadakan berbagai events juga dapat mendorong Taman Kota 2 BSD sebagai headline dalam artikel atau berita untuk memperkenalkan teman kepada kalangan masyarakat yang lebih luas.

\section{Kepegawaian}

Dalam melakukan pengelolaan Taman Kota 2 BSD, pemerintah perlu menetapkan pihak pengelola yang bertanggung jawab atas pengelolaan taman kepada dinas atau lembaga yang sesuai dan tepat, dimana setiap bidang pengelolaan taman memiliki tugas dan fungsi pada setiap masing - masing yang terstruktur dengan jelas dan membuat sistem pengelolaan berupa Standar Operasional Prosedur (SOP) yang terorganisir dan terperinci serta K3 untuk menciptakan kesehatan dan keselamatan kerja para setiap anggota pengelolaan guna meningkatkan produktivitas kerja para anggota pengelolaan taman. Selain itu, Penambahan sumber daya manusia yang memadai menjadi salah satu solusi untuk menangani masalah yang terdapat pada taman Kota 2 BSD. Dalam melakukan penambahan sumber daya manusia perlu 
diadakan proses seleksi penerimaan petugas yang lebih ketat dengan melakukan pengujian kompetensi dan mengadakan program pengembangan keterampilan berupa pelatihan (diklat) untuk menggunakan peralatan taman, menambah wawasan tentang taman dan segala pengetahuan yang terkait dengan taman serta melakukan pengujian kompetensi setiap 3 tahun untuk menjaga maupun meningkatkan kinerja petugas agar dapat melaksanakan tugas yang diberikan dengan baik.

\section{Pendanaan \& Dampak}

Dalam rangka melakukan pengelolaan taman yang efektif diperlukan anggaran untuk mengelola taman. Pada saat ini Taman Kota 2 BSD anggaran untuk melakukan penataan taman dan gaji staf kebersihan DLH ditanggung dari Anggaran Pendapatan dan Belanja Daerah (APBD) Kota Tangerang Selatan dan campur tangan CSR. Ketersediaan dana menjadi salah satu aspek penting dalam mempertahankan sistem taman yang berkelanjutan dan dampak ekonomi, sosial budaya yang dihasilkan dari kunjungan taman, maka perlu adanya perencanaan yang inovatif dan menganalisis anggaran untuk mengidentifikasi tingkat pendanaan yang dibutuhkan sehingga dapat menyeimbangkan kebutuhan pemanfaatan taman oleh pengunjung dan menjaga keanekaragaman hayati. Sumber daya keuangan taman dapat mencakup pemerintah, swasta, organisasi nasional maupun lokal serta kegiatan komersial langsung seperti biaya parkir, penjualan souvenir dan pelaksanaan events. Berikut ini merupakan rencana anggaran yang diperlukan untuk mengelola dan melakukan pengadaan fasilitas pada Taman Kota 2 BSD.

\section{KESIMPULAN DAN SARAN}

\section{Kesimpulan}

Berdasarkan hasil penelitian yang telah dilakukan pada Taman Kota 2 BSD terkait dengan pengelolaannya, Taman Kota 2 BSD merupakan salah satu ruang publik di Kota Tangerang Selatan yang memiliki luas sebesar $69.834 \mathrm{~m} 2$ dengan menggunakan konsep perpaduan antara area hijau dan biru. Dengan tujuan taman sebagai ruang terbuka hijau publik yang memiliki fungsi ekologi, sosial, budaya, ekonomi dan estetika kota, taman berperan penting sebagai peningkat kualitas kehidupan perkotaan dan menjadi tempat yang dapat meningkatkan nilai kota dengan fungsi keindahan, interaksi sosial, hasil hortikultura, dan fungsi lainnya yang dapat dilakukan oleh pengunjung pada waktu luang. Dengan demikian, dapat disimpulkan bahwa Taman Kota 2 BSD memiliki potensi yang dapat dikembangkan sebagai destinasi wisata dengan meningkatkan kualitas pengelolaannya. Pada saat Taman Kota 2 BSD masih dapat ditemukan beberapa permasalahan yang membutuhkan peningkatan baik dari baik dari pengelolaan taman dan juga pemenuhan kebutuhan sarana dan prasarana penambahan yang masih belum sesuai dengan harapan pengunjung akibat dari tidak adanya pengelolaan pada Taman Kota 2 BSD yang terstruktur.

Untuk mengetahui kinerja pengelolaan taman guna meningkatkan kualitas dan mempertahankan keberlanjutan taman dilakukan penyusunan strategi pengelolaan pada Taman Kota 2 BSD yang tepat dan efektif. Penyusunan strategi pengelolaan dilakukan dengan menggunakan 10 aspek pengelolaan berdasarkan kriteria penilaian kualitas dengan indikator pada setiap aspek pengelolaannya dalam mengevaluasi kinerja pengelolaan taman kota yaitu klasifikasi taman, aksesibilitas taman, penggunaan taman, pengelolaan pengunjung, pengelolaan aset taman, pengelolaan lingkungan taman, keterlibatan pihak lain, serta pemasaran \& distribusi, kepegawaian, pendanaan \& dampak. Konsep taman yang dimiliki taman yaitu dengan area hijau dan area biru menjadi salah satu kekuatan Taman Kota 2 BSD serta luas taman yang besar dengan berbagai macam fasilitas dan kegiatan didalamnya memungkinkan pengelola untuk dapat melakukan pengembangan yang lebih baik untuk meningkatkan interaksi sosial, ekonomi dan kebutuhan masyarakat Kota Tangerang Selatan dalam kehidupan 
perkotaan. Pengelolaan pada taman Kota 2 BSD perlu memastikan bahwa terdapat pemeliharaan, pengawasan, pemeriksaan dan perawatan terhadap seluruh aspek pengelolaan yang dilakukan secara rutin dan konsisten, melakukan perbaikan pada fasilitas yang mengalami kerusakan atau perlu peningkatan dan melakukan penambahan fasilitas yang dianggap belum memenuhi kebutuhan pengunjung Taman Kota 2 BSD. Setiap aspek - aspek pengelolaan tersebut perlu diperhatikan untuk menjaga kondisi Taman Kota 2 BSD agar tetap baik dan dapat dipertahankan pada keadaan yang sesuai dengan tujuan dan fungsi yang telah ditetapkan pada awal mula pembangunan taman serta untuk kenyamanan dan keamanan masyarakat saat berkunjung ke Taman Kota 2 BSD.

\section{Saran}

Berdasarkan hasil penelitian yang dilakukan dan kesimpulan dari penelitian, dalam rangka meningkatkan pengelolaan pada Taman Kota 2 BSD dengan mengembangkan potensi yang dimiliki, diperlukan pendekatan strategi pengelolaan taman dengan adanya dari upaya dari pihak lain seperti pemerintah dalam memutuskan lembaga atau dinas yang bertanggung jawab atas seluruh pengelolaan taman, meningkatkan kemampuan petugas dan lembaga/dinas secara berkelanjutan yang dilakukan secara sistematis atau pemberdayaan organisasi yang mampu mewujudkan eksistensi tama secara mandiri dan kolektif. Dalam melakukan pengelolaan Taman Kota 2 BSD terdapat aspek pengelolaan yang dikembangkan, perlu diperhatikan dengan penyesuaian tuntutan lingkungan dan tingkat kepentingannya berdasarkan persepsi pengunjung agar strategi dapat diimplementasikan sesuai dengan situasi dan kebutuhan. Terdapat dua pendekatan yang menjadi rekomendasi untuk melakukan strategi pengelolaan pada Taman Kota 2 BSD, yaitu: (1) Pendekatan pengembangan kemampuan organisasi, dan (2) Pendekatan Pemberdayaan Masyarakat

\section{REFERENSI}

Arifin, S., \& Arifin, H. (2005). Pemeliharaan Taman. Jakarta: Penebar Swadaya, 2005. Jakarta: Penebar Swadaya.

David, F. R., \& David, F. (2015). Strategic Management. Boston: Pearson.

Inglis, J., Whitelaw, P., \& Pearlman, M. (2005). Best Practice in Sstrategic Park Management: Towards an Integrated Park Management Model. Australia: CRC for Sustainable Tourism.

Kasyanov, V. F., \& Silin, R. V. (2019). Method For Multi-Criteria Evaluation of Urban Parks. IOP Conf. Series: Materials Science and Engineering, 687.

Menteri Pekerjaan Umum. (2008). Pedoman Penyediaan dan Pemanfaatan Ruang Terbuka Hijau di Kawasan Perkotaan. Jakarta.

Naway, F. A. (2016). Strategi Pengelolaan Pembelajaran. Gorontalo: Ideas Publishing.

Rangkuti, F. (2002). Measuring Customer Satisfaction : gaining customer, relationship strategy - Teknik Mengukur dan Strategi Meningkatkan Kepuasan Pelanggan. Jakarta: PT Gramedia Pustaka Utama.

Sukarna. (2011). Dasar - Dasar Manajemen. Bandung: Mandar Maju. 